\title{
Pendekatan Model Nonparametrik untuk Memodelkan Hubungan Antara Jumlah Uang Beredar dan Indeks Harga Konsumen di Indonesia Tahun 1969-2017
}

\author{
Pardomuan Robinson Sihombing ${ }^{1}$ \\ ${ }^{1}$ Badan Pusat Statistik \\ ${ }^{1}$ robinson@bps.go.id
}

\begin{abstract}
Inflation is one of the macroeconomic variables of concern to the government in addition to economic growth, unemployment and poverty. Inflation is measured by the Consumer Price Index (CPI). According to the quantity theory of the classics, argues that the price level is determined by the amount of money in circulation, prices will rise if there is an increase in the money supply, assuming the amount of goods offered is fixed, while the amount of money is doubled, sooner or later the price will doubled. Often the relationship between macroeconomic variables is not always linear, it can be exponential, logarithmic, or highly fluctuating patterns. This nonlinear relationship cannot be forced using parametric regression which generally uses the Ordinary Least Square (OLS) or Maximum Likelihood Estimation (MLE) which often implies the existence of certain distributions and linear data patterns. In some literatures, researches using a linear model with OLS, for describing the relationship between CPI and money supply. This research uses several non parametric approaches, namely kernel and spline functions. The results obtained are a strong positive relationship between money supply and CPI, where money supply has a significantly positive effect on CPI. The most suitable non parametric method to describe the relationship pattern between CPI and money supply is the smoothing spline method with Generalized Cross Validation (GCV) parameter optimization method with the smallest RMSE and MAPE criteria and functions that can follow data patterns smoothly.
\end{abstract}

Keywords: CPI, money supply, non parametric, kernel, spline.

\section{Pendahuluan}

Inflasi adalah salah satu variabel makroekonomi yang menjadi perhatian pemerintah selain pertumbuhan ekonomi, pengangguran, dan kemiskinan. Inflasi juga merupakan salah satu variabel yang sering diperhatikan agar tidak tercapai hiperinflasi (inflasi double digit). Akan tetapi selain memiliki dampak negatif, inflasi juga memiliki dampak positif, dimana inflasi dibutuhkan bagi pertumbuhan ekonomi suatu negara. Setiap tahun dalam setiap menyusun Anggaran Pendapatan Belanja Negara (APBN), pemerintah bersama DPR selalu berhati-hati dalam menetapkan tingkat inflasi, karena setiap penetapan tingkat inflasi berkaitan dengan tingkat pertumbuhan yang ingin dicapai. Secara umum, inflasi diartikan suatu keadaan dimana meningkatnya harga-harga secara umum dan terus-menerus yang berhubungan dengan mekanisme pasar, artinya konsumsi masyarakat yang cenderung naik. Selain itu inflasi juga dapat dikatakan sebagai proses menurunnya nilai mata uang secara terus-menerus, yang dapat menyebabkan meningkatnya persediaan uang, yang sering dianggap penyebab naiknya harga. Inflasi 
diukur dengan Indeks Harga Konsumen (IHK), yang dihitung dan dipublikasikan oleh Badan Pusat Statistik. Dalam menyusun IHK, data harga konsumen diperoleh dari 82 kota, mencakup antara 225-462 barang dan jasa yang dikelompokkan ke dalam tujuh kelompok pengeluaran yaitu: bahan makanan; makanan jadi, minuman, rokok dan tembakau; perumahan, air, listrik, gas dan bahan bakar; sandang; kesehatan; pendidikan, rekreasi dan olah raga; serta transpor, komunikasi dan jasa keuangan. Setiap kelompok terdiri dari beberapa sub kelompok, dan dalam setiap sub kelompok terdapat beberapa komoditas. Lebih jauh, komoditas-komoditas tersebut memiliki beberapa kualitas atau spesifikasi.

Inflasi dapat diartikan adanya kecenderungan kenaikan harga barang atau jasa secara terus menerus dan kenaikan tersebut meluas ke seluruh sektor perekonomian yang lain karena ketidakseimbangan arus uang dan barang yang tersedia. Keeratan hubungan inflasi dengan jumlah uang beredar tidak dapat dilihat dalam jangka pendek. Teori inflasi ini bekerja paling baik dalam jangka panjang, bukan dalam jangka pendek, dengan demikian hubungan antara pertumbuhan uang dan inflasi dalam data bulanan tidak akan seerat hubungan keduanya jika dilihat selama periode 10 tahun.

Pada umumnya, inflasi yang terjadi di suatu negara sangat dipengaruhi oleh faktor-faktor domestik dan faktor-faktor dari luar negeri. Beberapa faktor-faktor domestik tersebut antara lain: tingkat suku bunga, jumlah uang yang beredar, pajak penghasilan, defisit anggaran, dan lain-lain. Faktor dari luar negeri lebih disebabkan oleh tingkat keterbukaan perekonomian dari suatu negara terhadap ekonomi dunia yang dapat dilihat dari neraca pembayarannya baik neraca perdagangan (current account) ataupun neraca modal (capital account). Menurut Mankiw [1] dalam keadaan seimbang, suatu perekonomian tingkat harga dipengaruhi oleh jumlah uang beredar sehingga dapat dikatakan adanya keeratan hubungan tingkat harga (inflasi) dan jumlah uang beredar tidak dapat dilihat dalam jangka pendek.

Seringkali hubungan antara variabel makroekonomi tidak selalu berbentuk linier, bisa saja berhubungan secara eksponensial, logaritmik, maupun pola yang sangat berfluktuatif. Hubungan yang tidak linier ini tidak dapat dipaksakan menggunakan regresi parametrik yang pada umumnya menggunakan metode estimasi Ordinary Least Square (OLS) maupun Maximum Likelihood Estimation (MLE) yang seringkali mengisyaratkan adanya distribusi tertentu dan pola data yang linier. Berdasarkan permasalahan di atas, peneliti ingin mengidentifikasi pola hubungan jumlah uang beredar terhadap inflasi (yang diaproksimasi dengan IHK) dengan pendekatan regresi nonparametrik. 
Volume 3 No. 1 May 2020

\section{Kajian Teoritis}

2.1. Teori Inflasi. Inflasi dapat diartikan adanya kecenderungan kenaikan harga barang atau jasa secara terus menerus dan kenaikan tersebut meluas ke seluruh sektor perekonomian yang lain karena ketidakseimbangan arus uang dan barang yang tersedia. Keeratan hubungan inflasi dengan jumlah uang beredar tidak dapat dilihat dalam jangka pendek. Teori inflasi ini bekerja paling baik dalam jangka panjang, bukan dalam jangka pendek, dengan demikian hubungan antara pertumbuhan uang dan inflasi dalam data bulanan tidak akan seerat hubungan keduanya jika dilihat selama periode 10 tahun.

2.2. Teori Jumlah Uang Beredar. Menurut Boediono [2] salah satu kebijakan moneter yang sering digunakan oleh otoritas-otoritas moneter Bank Indonesia untuk mempengaruhi kondisi makroekonomi yang dilaksanakan melalui pasar uang sedangkan menurut Nopirin [3] kebijakan moneter yang secara khusus bisa diartikan sebagai tindakan yang dilakukan oleh otoritas moneter untuk mempengaruhi jumlah uang beredar dan dapat mempengaruhi kegiatan ekonomi suatu Negara. Total simpanan uang dalam suatu kegiatan perekonomian dalam satu periode tertentu yang umumnya satu tahun sering disebut sebagai Jumlah Uang Beredar (JUB).

Menurut teori kuantitas dari kaum klasik, berpendapat bahwa tingkat harga ditentukan oleh jumlah uang beredar, harga akan naik jika ada penambahan jumlah uang beredar dengan asumsi jumlah barang yang ditawarkan tetap, sedangkan jumlah uang ditambah menjadi dua kali lipat, maka cepat atau lambat harga akan naik menjadi dua kali lipat.

2.3. Tinjauan Pustaka. Berdasarkan penelitian Ari dan Arka [4] determinan jumlah uang beredar dan tingkat inflasi di Indonesia tahun 1984-2014 dengan menggunakan analisis jalur. Temuannya menunjukkan bahwa jumlah uang beredar berpengaruh signifikan terhadap inflasi. Hasil penelitian Afrizal [5] tentang pengaruh jumlah uang beredar terhadap inflasi di Indonesia, data bulanan periode Januari 2001-April 2014, model yang digunakan Error Correction Models (ECM). Berdasarkan hasil penelitian diperoleh, pada jangka pendek jumlah uang beredar tidak berpengaruh atau tidak signifikan terhadap laju inflasi di Indonesia, tetapi inflasi pada bulan tersebut dipengaruhi oleh jumlah uang beredar pada bulan sebelumnya. Pada jangka panjang jumlah uang beredar berpengaruh atau tidak signifikan terhadap inflasi. 


\section{Metode Penelitian}

3.1. Ruang Lingkup Penelitian. Penelitian ini mengambil data makroekonomi jumlah uang beredar dan Indeks Harga Konsumen (IHK) yang merupakan aproksimasi dari inflasi. Data dalam penelitian ini diambil dari data tahunan, mulai tahun 1969 hingga tahun 2017. Ruang lingkup dalam penelitian ini jumlah uang beredar sebagai variabel penjelas (independen/prediktor/eksogen) sedangkan IHK sebagai variabel terikat (dependen/respon/endogen).

3.2. Metode Pengumpulan Data. Data dalam penelitian ini merupakan data sekunder yang diambil dari website world bank melalui link https://data.worldbank.org/country/ indonesia?view=chart. Data yang digunakan memperhitungkan penggunaan tahun dasar pada data IHK. Selanjutnya data diolah oleh peneliti menyesuaikan format yang dapat dibaca oleh software R.

3.3. Metode Analisis. Penelitian ini menggunakan analisis regresi yang merupakan metode analisis data untuk menggambarkan hubungan antara variabel respon dengan satu atau beberapa variabel prediktor. Misalkan $X$ adalah variabel prediktor dan $Y$ adalah variabel respon untuk $n$ pengamatan berpasangan $\left\{\left(x_{i}, y_{i}\right)\right\}_{i}=l^{n}$ maka hubungan linear antara variabel prediktor dan variabel respon tersebut dapat dinyatakan sebagai berikut: $y_{i}=m\left(x_{i}\right)+\varepsilon_{i}, i=1,2, \ldots, n$ dengan $\varepsilon_{i}$ adalah sisaan yang diasumsikan independen dengan mean nol dan variansi $\sigma^{2}$, serta $m\left(x_{i}\right)$ adalah fungsi regresi atau kurva regresi [6]. Pendekatan yang digunakan untuk mengestimasi fungsi regresi ada dua jenis, yaitu pendekatan parametrik dan nonparametrik. Bentuk hubungan antara variabel respon dengan variabel prediktor dalam pendekatan parametrik diketahui dari bentuk kurva regresi, misalnya diasumsikan membentuk pola linear, kuadratik, eksponensial, dan polynomial [6]. Model regresi linear dalam regresi parametrik harus memenuhi asumsi yang ketat yaitu sisaan berdistribusi normal dan memiliki variansi yang konstan.

3.4. Regresi Nonparametrik. Dalam regresi nonparametrik hubungan fungsional antar variabel tidak diketahui, dan diharapkan dapat mencari sendiri bentuk estimasinya sehingga memiliki fleksibilitas yang tinggi. Kurva regresi hanya diasumsikan termuat dalam suatu ruang fungsi yang berdimensi tak hingga dan merupakan fungsi mulus (smooth). Estimasi fungsi $z\left(x_{i}\right)$ dilakukan berdasarkan data pengamatan dengan menggunakan teknik smoothing tertentu. Ada beberapa teknik smoothing yang dapat 
digunakan antara lain estimator histogram, kernel, deret orthogonal, spline, $k$-NN, deret fourier, dan wavelet.

3.4.1. Estimator Densitas Kernel. Estimator kernel merupakan pengembangan dari estimator histogram. Estimator kernel diperkenalkan oleh Rosenblatt dan Parzen sehingga disebut estimator densitas kernel Rosenblatt-Parzen [7, 8]. Penaksir densitas kernel memberikan sebaran peluang untuk tiap observasi yang tidak selalu merata dalam interval yang tetap, tetapi secara halus di sekitar beberapa observasi, biasanya secara simetris. Secara umum kernel $K$ dengan bandwidth $h$ didefinisikan sebagai:

$$
K_{h}(x)=\frac{1}{h} K\left(\frac{x}{h}\right), \text { untuk }-\infty<x<\infty, h>0
$$

serta memenuhi:

$K(x) \geq 0$, untuk semua $x$

$$
\begin{aligned}
& \int_{-\infty}^{\infty} K(x) d x=1 \\
& \int_{-\infty}^{\infty} x^{2} K(x) d x=\sigma^{2}>0 \\
& \int_{-\infty}^{\infty} x K(x) d x=0
\end{aligned}
$$

maka estimator densitas kernel untuk fungsi densitas $f(x)$ adalah

$$
\hat{f}_{h}=\frac{1}{n} \sum_{i=1}^{n} K_{h}\left(x-x_{i}\right)=\frac{1}{n h} K\left(\frac{x-x_{i}}{h}\right)
$$

Dari persamaan (1) dan (2) terlihat bahwa $f_{h}(x)$ tergantung pada fungsi kernel $K$ dan parameter $h$. Bentuk bobot kernel ditentukan oleh fungsi kernel $K$, sedangkan ukuran bobotnya ditentukan oleh parameter pemulus $h$ yang disebut bandwidth. Peran bandwidth seperti lebar interval pada histogram. Beberapa jenis fungsi kernel antara lain:

Kernel Uniform : $K(x)=\frac{1}{2} I(|x| \leq 1)$

Kernel Triangle : $K(x)=(1-|x|) I(|x| \leq 1)$

Kernel Epanechnikow: $K(x)=\frac{3}{4}\left(1-x^{2}\right) I(|x| \leq 1)$

Kernel Kuartik: $K(x)=\frac{11}{16}\left(1-x^{2}\right) I(|x| \leq 1)$

Kernel Triweight : $K(x)=\frac{35}{32}\left(1-x^{2}\right) I(|x| \leq 1)$ 
Kernel Cosinus : $K(x)=\frac{\pi}{4} \cos \left(\frac{\pi}{2} x\right) x I(|x| \leq 1)$

Kernel Gaussian: $K(x)=\frac{1}{\sqrt{2 \pi}}\left(\frac{1}{2}\left(-x^{2}\right)\right),-\infty<x<\infty$

dengan $I$ adalah indikator. Pada penelitian ini menggunakan kernel Gaussian/Normal.

3.4.2. Regresi Kernel. Regresi kernel adalah teknik statistika nonparametrik untuk mengestimasi fungsi regresi $m(x)$ pada model regresi nonparametrik $y_{i}=m\left(x_{i}\right)+\varepsilon_{i}$. Nadaraya dan Watson pada tahun 1964 mendefinisikan estimator regresi kernel sehingga disebut estimator Nadaraya-Watson $[9,10]$.

$$
\hat{m}(x)=\frac{\frac{1}{n} \sum_{i=1}^{n} K_{h}\left(x-x_{i}\right) y_{i}}{\frac{1}{n} \sum_{i=1}^{n} K_{h}\left(x-x_{i}\right)}=\sum_{i=1}^{n} w_{h i}(x) y_{i} \text { dengan } w_{h i}(x)=\frac{\frac{1}{h} K\left(\frac{x-x_{i}}{h}\right)}{\frac{1}{h} \sum_{i=1}^{n} K\left(\frac{x-x_{i}}{h}\right)}=\frac{K\left(\frac{x-x_{i}}{h}\right)}{\frac{1}{h} \sum_{i=1}^{n} K\left(\frac{x-x_{i}}{h}\right)}
$$

Aproksimasi $m(X)$ secara lokal dengan sebuah konstanta $m(X) \approx m_{0}$ melalui kuadrat terkecil lokal

$\sum_{i=1}^{n}\left(Y_{i}-\beta\right)^{2} K_{h}\left(X_{i}-x\right)$

dengan model regresi polinomial

$Y_{i}=\beta_{0}+\beta_{1}\left(X_{i}-x\right)+\beta_{2}\left(X_{i}-x\right)^{2}+\ldots+\beta_{p}\left(X_{i}-x\right)^{p}+\varepsilon_{i}$

dengan penaksir koefisien regresi polinomial lokal adalah

$\hat{\beta}=\left(X^{T} W X\right)^{-1} X^{T} W X$

dengan $W=\operatorname{diag}\left(W_{i i}\right)$ dengan $W_{i i}=K_{h}\left(X_{i}-x\right), Y=\left(Y_{1}, \ldots, Y_{n}\right)^{T}$

\subsubsection{Regresi Kernel Menggunakan Local Polinomial Estimator (LPE) Teknik} regresi nonparametrik lain untuk menaksir fungsi regresi $m(X)$ adalah dengan menggunakan LPE, yaitu suatu metode regresi nonparametrik, dimana fungsi regresi $m(X)$ ditaksir menggunakan bentuk polinomial. Estimasi $m(X)$ menggunakan LPE akan melibatkan fungsi bobot yaitu fungsi kernel $K_{h}\left(X_{i}-x\right)$. Bentuk bobot polinomial lokal ditentukan oleh fungsi kernel $K($.$) , sedangkan ukuran bobot ditentukan oleh$ parameter $h$ yang disebut bandwidth.

3.4.4. Regresi spline. Salah satu model regresi dengan pendekatan nonparametrik yang dapat digunakan untuk menduga kurva regresi adalah regresi spline. Regresi spline merupakan suatu pendekatan pemodelan pada plot data dengan tetap memperhitungkan 
kemulusan kurva. spline merupakan suatu polinomial dimana segmen-segmen polinomial yang berbeda ditautkan pada knots $k_{1}, k_{2}, k_{3}, \ldots, k_{r}$ dan kontinu sehingga bersifat fleksibel dibandingkan polinomial biasa. spline merupakan model polinomial yang tersegmen (piecewise polynomial).

spline masih bersifat kontinu pada knot-knotnya. spline mempunyai titik knot yang maksudnya adalah titik perpaduan bersama dimana terjadi perubahan perilaku kurva. spline dapat menyesuaikan diri secara efektif terhadap data yang ada, sehingga didapatkan hasil yang mendekati kebenaran. Estimasi terhadap $f(x)$ adalah $f_{\lambda}(x)$ yakni estimator yang mulus [6]. Bentuk umum regresi spline orde ke- $m$ adalah

$$
f(x)=\beta_{0}+\sum_{j=1}^{m} \beta_{j} x^{j}+\sum_{k=1}^{N} \beta_{j+k}\left(x-K_{k}\right)^{m-1}+\varepsilon
$$

3.4.5 Regresi $\boldsymbol{B}$-splines. Regresi splines adalah salah satu model dengan pendekatan nonparametrik yang berupa modifikasi dari fungsi polinomial tersegmen. Bentuk estimator spline sangat dipengaruhi oleh nilai parameter penghalus yang pada hakekatnya adalah penentuan lokasi titik-titik knot. Pemilihan knot optimal dalam regresi spline berarti pemilihan lokasi titik-titik knot yang memberikan nilai Generalized Cross Validation (GCV) dan Mean Square Error (MSE) terkecil. Oleh karena itu, penentuan titik knot optimal merupakan persoalan yang sangat penting dalam estimasi regresi spline.

Penaksir $B$-splines adalah salah satu metode yang digunakan untuk menaksir kurva regresi nonparametrik. Model B-splines dengan titik knot digunakan untuk menyelesaikan kelemahan model spline pada saat orde yang tinggi, titik knot yang banyak atau knot yang terlalu dekat yang akan membentuk matriks dalam perhitungan yang hampir singular sehingga persamaan normal sulit diselesaikan. Metode yang digunakan dalam menaksir parameter B-splines adalah Metode Kuadrat Terkecil (Ordinary Least Square) yang didefinisikan secara rekursif. B-splines merupakan fungsi piecewise polynomial dengan support lokal untuk derajat polynomial tertentu. B-splines ke- $j$ dengan derajat $v$ berdasarkan deretan $\operatorname{knot} t_{0}, \ldots, t_{u}$ untuk $j=1, \ldots, v+u$ dinotasikan dengan formula rekursif berikut:

$$
B_{j}(x ; v)=\frac{x+t_{j}}{t_{j+v-1}-t_{j}} B_{j}(x ; v-1)+\left(1-\frac{x-t_{j} B_{j}(x ; v)+1}{t_{j+v}-t_{j+1}}\right) B_{j+1}(x ; v-1)
$$

dengan 
$B_{j}(x: 0)=\left\{\begin{array}{c}1, \text { jika } \\ 0, \text { lainnya }\end{array} t_{j} \leq x \leq t_{j+1}\right.$

Apabila $B$-splines dinormalisasi maka; $\forall x: \sum_{j=1}^{v+1} B_{j}(x ; v)=1$

Pada regresi mean $Y_{t}=f\left(x_{i}\right)+\varepsilon_{i}$ diasumsikan $\varepsilon_{i}$ berdistribusi identik dan independen dengan rata-rata nol dan finite varians $\sigma^{2} . f($.$) diasumsikan merupakan$ kombinasi yang halus yang dapat didekati dengan kombinasi linier dari $B$-splines:

$$
f(x) \approx \sum_{j=1}^{m} \alpha_{j} \beta_{j}(x ; v)
$$

dengan $\alpha=\left(\alpha_{1}, \ldots, \alpha_{m}\right)$ merupakan vektor koefisien dari basis $B$-splines $\beta_{j}(. ; v)$ dengan derajat $v$ dan $u+1$ knot equidistant untuk $j=1, \ldots, u+v=m$.

Fungsi objektif regresi $B$-splines:

$$
\hat{\alpha}=\arg \min _{\alpha}\left\{\sum_{i=1}^{n}\left(Y_{i}-\sum_{j=1}^{m} \alpha_{j} \beta_{j}\left(x_{i}, v\right)\right)^{2}\right\}
$$

$f(x)$ bisa ditaksir melalui persamaan berikut:

$$
\hat{f}(x) \approx \sum_{j=1}^{m} \alpha_{j} \beta_{j}(x ; v)
$$

3.4.6. Pemilihan Parameter Penghalus. Pada regresi nonparametrik, bentuk fungsi $f$ tidak diketahui, fungsi $f$ diasumsikan smooth dalam arti $f$ merupakan anggota ruang Sobolev $W_{2}^{m}[0,1]=\left\{f: f^{(k)}\right\}=0,1, \ldots, m-1$ kontinu absolut pada [0,1] dan $f^{(m)}$ elemen $L_{2}[0,1]$ dengan $L_{2}[0,1]$ menyatakan himpunan fungsi-fungsi kuadrat terintegral pada interval $[0,1]$. Idealnya akan dipilih suatu nilai $\lambda$ yang meminimumkan fungsi kerugian $L(\lambda)$, akan tetapi dalam regresi nonparametrik tidak dapat dilakukan secara nyata sebab $L(\lambda)$ masih memuat fungsi $f$ yang tidak diketahui. Data perlu diestimasi dan kemudian estimatornya diminimumkan terhadap $\lambda$ untuk mendapat estimator $f$ yang paling baik [6]. Salah satu pemilihan parameter penghalus $\lambda$ adalah menggunakan metode Generalized Cross Validation (GCV). Ide dasar dari GCV adalah memodifikasi Cross Validation (CV) [11], dengan formula:

$$
\begin{aligned}
& C V(\lambda)=n^{-1} \sum_{j=1}^{n}\left(y_{j}-f_{\lambda}^{[j]}(t)\right)^{2} \\
& G C V(\lambda)=n^{-1} \sum_{j=1}^{n} \frac{\left(y_{j}-f_{\lambda}\left(t_{j}\right)\right)^{2}}{\left(1-n^{-1} \sum_{i=1}^{n} a_{i j}(\lambda)\right)^{2}}
\end{aligned}
$$




\section{Hasil dan Pembahasan}

4.1. Statistik Deskriptif. Statistik deskriptif melihat ukuran-ukuran pemusatan data sehingga dapat melihat perkembangan nilai variabel penelitian selama periode penelitian.

Tabel 1. Deskriptif Variabel Penelitian

\begin{tabular}{ccc}
\hline Ukuran & IHK & JUB (miliar) \\
\hline Minimum & 1,028 & 230 \\
1st Q & 6,236 & 9.819 \\
Median & 16,326 & 14.4063 \\
Mean & 40,427 & 963.473 \\
3rd Q & 68,685 & 1.202 .762 \\
Maximum & 142,182 & 5.419 .165 \\
\hline
\end{tabular}

Jika dinilai IHK pada tahun dasar 2010, maka IHK tahun 1969 bernilai 1,028 sedangkan IHK tahun 2017 bernilai 142,182. Peningkatan harga selalu terjadi dalam rangka peningkatan pertumbuhan ekonomi. Jumlah uang beredar dalam satuan milliar rupiah, pada tahun 1969 jumlah uang beredar sebesar 230 milliar rupiah dan pada tahun 2017 telah mencapai 5.419 triliun rupiah. Selanjutnya dilakukan pengecekan normalitas masing-masing variabel penelitian dengan uji Kolmogorov (Tabel 2).

Tabel 2. Uji Normalitas Variabel Penelitian

\begin{tabular}{ccc}
\hline Uji & Nilai- $p$ JUB & Nilai- $p$ IHK \\
\hline Kolmogorov & $3,33 \times 10^{-16}$ & $3,33 \times 10^{-6}$
\end{tabular}

Berdasarkan hasil pada Tabel 2 dapat diketahui bahwa untuk data JUB dan data IHK dengan menggunakan pendekatan uji Kolmogorov dikatakan datanya tidak berdistribusi normal karena nilai $p<0,05$.

4.2. Korelasi Antar Variabel Penelitian. Pada Gambar 1 dapat dilihat hubungan antara jumlah uang beredar tidak berbentuk linier, cenderung berbentuk fungsi akar dan ada beberapa observasi menumpuk pada nilai-nilai awal. Jika dicari keeratan hubungan antara JUB dan IHK dengan menggunakan korelasi Pearson didapat hasil sebesar 0,9615434 yang artinya bahwa terdapat hubungan positif yang kuat antara JUB dengan IHK. Tentu saja korelasi Pearson ini berlaku jika hubungan antara dua variabel berbentuk linier dan berasal dari distribusi normal (akan dicek pada bagian selanjutnya). 


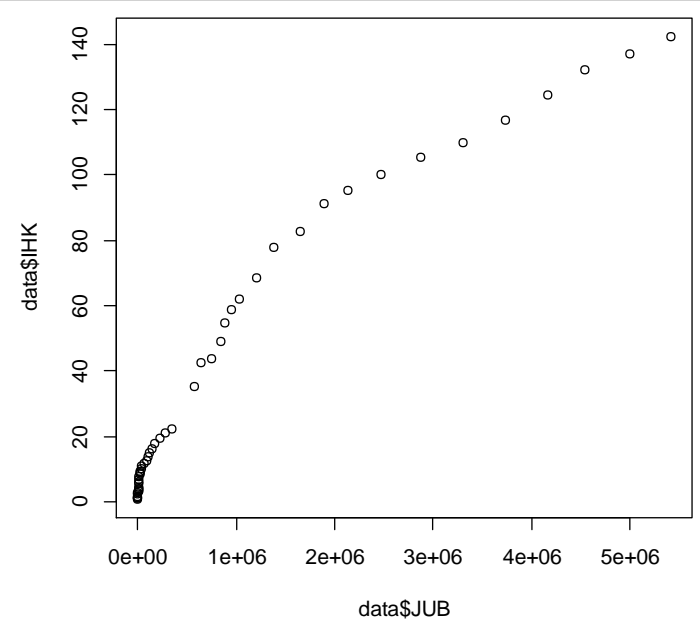

Gambar 1. Plot Hubungan JUB dan IHK

4.3. Regresi Parametrik. Dalam penelitian ini menggunakan analisis regresi linier sederhana dengan pendekatan OLS, didapat hasil sebagai berikut:

Tabel 3. Hasil Regresi Parametrik

\begin{tabular}{clllll}
\hline Coefficients & Estimate & Std.error & $t$ & $\operatorname{Pr}(>|t|)$ & Kesimpulan \\
\hline (Intercept $)$ & $1.27 \times 10^{1}$ & 2.11 & 6.025 & $2.47 \times 10^{7}$ & Signifikan \\
$X$ & $2.88 \times 10^{5}$ & $1.20 \times 10^{-6}$ & 24.001 & $2.00 \times 10^{16}$ & Signifikan \\
$F$-statistic: & 576.1 & Nilai- $p \mathrm{~F}$ & $2.20 \times 10^{16}$ & & \\
$R$-square & 0.9246 & & & & \\
\hline
\end{tabular}

Dari hasil regresi di atas didapat koefisien determinasi sebesar 0,9246 artinya variasi IHK mampu dijelaskan oleh variasi JUB sebesar 92,46 persen sisanya 7,54 persen oleh variabel lain di luar model. Nilai- $p F$-statistic $=2,2 \times 10^{-16}<0.05$ mengindikasikan bahwa modelnya sudah fit, hal ini didukung dengan hasil uji parsial/uji $T$ dengan nilai- $p$ $=2 \times 10^{-16}<0.05$ mengindikasikan bahwa JUB mempengarui IHK dengan koefisien sebesar $2,88 \times 10^{-5}$.

4.3.1. Pemeriksaan Asumsi Normalitas. Selanjutnya untuk memastikan bahwa modelnya dapat digunakan untuk tujuan inferensia maka diperlukan pengetahuan akan bentuk distribusinya. Berdasarkan hasil uji Kolmogorov diperoleh nilai $p$ sebesar $3,69 \times 10^{-14}$ sehingga dapat disimpulkan bahwa data tidak normal karena nilai $p<0,05$. Karena tidak memenuhi asumsi distribusi normal, harus dilakukan tindakan perbaikan yaitu dengan menggunakan regresi nonparametrik. 
4.3.2. Pemeriksaan Asumsi Linearitas. Hal yang paling mendasar untuk diuji adalah linearitas. Hal ini untuk meyakinkan bahwa persamaan antara kedua variabel berbentuk linier sehingga dapat diestimasi dengan tepat. Dari hasil uji Ramsey Reset Test dapat dikatakan modelnya tidak berdistribusi normal karena nilai $p=2,2 \times 10^{-6}<0,05$.

\subsection{Regresi Nonparametrik}

4.4.1. Teknik Optimalisasi Bandwidth dan Knot. Permasalahan utama pada estimasi kernel adalah pada pemilihan bandwidth, bukan pada pemilihan kernelnya. Bandwidth adalah parameter pemulus yang berfungsi untuk mengontrol kemulusan dari kurva yang diestimasi. Bandwidth yang terlalu kecil akan menghasilkan kurva yang under-smoothing jika terlalu lebar akan menghasilkan kurva yang over-smoothing. Hasil fungsi kernel pada Nadaraya Watson Estimation (NEW) dan LPE menggunakan metode direct plug-in untuk memilih bandwidth, seperti yang dideskripsikam oleh Wand and Jones [12]. Hasil yang didapat bandwidth optimal sebesar 196583,2. Fungsi spline menggunakan CV dan GCV dimana pada sintaks yang digunakan pada umumnya defaultnya CV atau tertulis $\mathrm{CV}=\mathrm{TRUE}$ dan GCV jika tertulis CV= FALSE. Pada metode smoothing spline dengan metode $\mathrm{CV}$ di dapat parameter spar $=0,4175172$ dan lambda $=1,4 \times 10^{-13}$ sedangkan dengan metode GCV sebesar spar $=0,2880573$ dan lambda $=1,6 \times 10^{-14}$. Sedangkan untuk B-spline mencari knot optimal menggunakan default pada paket $\mathrm{R}$.

Tabel 4. Nilai RMSE dan MAPE Model Regresi Parametrik dan Nonparametrik

\begin{tabular}{clcc}
\hline No & Model & RMSE & MAPE \\
\hline 1 & OLS & 12.07259 & 1.516159 \\
2 & NWE & 2.676403 & 0.557396 \\
3 & SS_CV & 0.020307 & 0.004079 \\
4 & SS_GCV & 0.010297 & 0.002569 \\
5 & SS_BS & 2.439855 & 0.421202 \\
6 & LPE & NA & 1.332917 \\
\hline
\end{tabular}

4.4.2. Nilai RMSE dan MAPE Model Regresi Parametrik dan Regresi Nonparametrik. Untuk melihat bahwa model yang dihasilkan akurat atau tidak, dapat dilihat dari nilai RMSE dan MAPE. Semakin kecil nilai RMSE dan MAPE maka dapat 
dikatakan modelnya semakin baik. Nilai RMSE dan MAPE dari keenam model dapat dilihat pada Tabel 4.

Berdasarkan hasil pada Tabel 4 dapat diketahui bahwa model terbaik dengan RMSE dan MAPE terkecil adalah model smoothing spline dengan optimalisasi metode GCV. Pada model LPE tidak menghasilkan nilai RMSE karena nilai y predict yang dihasilkan kemungkinan tidak berasal dari nilai $x$ observasi, melainkan nilai neighborhood dari observasi $x$.

4.4.3. Plot Model yang Dihasilkan. Pada Gambar 2 didapatkan beberapa plot yang dihasilkan baik dari regresi parametrik maupun regresi nonparametrik. Untuk kurva fungsi yang paling halus adalah regresi dengan OLS tetapi nilai-nilai observasi jauh dari garis regresi yang dihasilkan. Sedangkan kurva yang paling bagus mengikuti pola observasi adalah kurva smoothing spline. Kurva LPE pada bagian akhir observasi sanga kasar. Kurva $B$-spline dan NWE juga mengikuti pola data hanya kurang optimal dalam mencapai titik terendah observasi. Khusus untuk regresi nonparametrik $B$-spline juga dihasilkan persamaan seperti pada regresi parametrik dengan OLS.

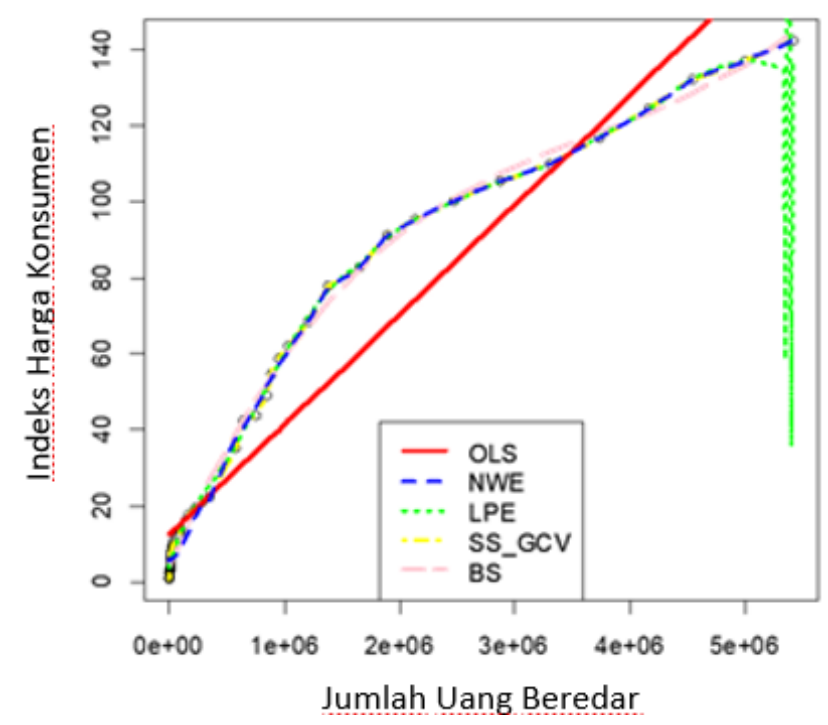

Gambar 2. Perbandingan OLS, NWE, LPE, Smoothing spline, dan B-spline

Dari hasil regresi pada persamaan (3) didapat koefisien determinasi sebesar 0,9967 artinya variasi IHK mampu dijelaskan oleh variasi JUB dalam model sebesar $99,67 \%$ sisanya $0.33 \%$ oleh variabel lain di luar model. Nilai- $p$ F statistic $=2,2 \times 10^{-16}<$ 0,05 mengindikasikan bahwa modelnya sudah fit, hal ini didukung dengan hasil uji parsial/ uji $T$ untuk seluruh parameter dengan nilai- $p=2 \times 10^{-16}<0.05$ mengindikasikan 
bahwa JUB mempengaruhi IHK. Berdasarkan Tabel 4 persamaan regresi $B$-spline dapat dituliskan dengan

$$
\hat{f}(x)=4.6416+123.9313 B_{1}(x ; 3)+97.2404 B_{2}(x ; 3)+139.8194 B_{3}(x ; 3)
$$

Tabel 4. Hasil Regresi Nonparametrik B-spline

\begin{tabular}{clclll}
\hline Coefficients: & Estimate & Std. & Error & $\operatorname{Pr}(>|\mathrm{t}|)$ & Kesimpulan \\
\hline (Intercept) & 4.6416 & 0.5088 & 9.122 & $8.53 \times 10^{-12}$ & Signifikan \\
bs $(x$, degree $=3) 1$ & 123.9313 & 3.0253 & 40.965 & $2.00 \times 10^{-16}$ & Signifikan \\
$\operatorname{bs}(x$, degree $=3) 2$ & 97.2404 & 3.9713 & 24.486 & $2.00 \times 10^{-16}$ & Signifikan \\
bs $(x$, degree $=3) 3$ & 139.8194 & 2.1798 & 64.144 & $2.00 \times 10^{-16}$ & Signifikan \\
F-statistic: & 4854 & Nilai- $p$ F statistic: $:$ & $2.20 \times 10^{-16}$ & & \\
R-squared: & 0.9969 & Adjusted & R-squared: & 0.9967 & \\
\hline
\end{tabular}

\section{Kesimpulan dan Saran}

Terdapat hubungan positif yang kuat antara JUB dengan IHK, dimana JUB berpengaruh secara signifikan positif terhadap IHK. Metode nonparametrik yang paling cocok untuk menggambarkan pola hubungan antara IHK dan JUB adalah metode smoothing spline dengan metode optimasi parameter GCV. Penelitian selanjutnya dapat menambahkan variabel penjelas lainnya yang mempengaruhi IHK agar diperoleh hasil yang lebih representative serta dapat menggunakan pendekatan model spline yang lain.

\section{Daftar Pustaka}

[1] Mankiw, N. G. Teori Makroekonomi. Erlangga. Jakarta. 2003.

[2] Boediono. Ekonomi Moneter. BPFE. Yogyakarta. 2000.

[3] Nopirin. Ekonomi Moneter Buku I. BPFE. Yogyakarta. 2014.

[4] Ari, N. L. G. dan Arka, S. Determinan Jumlah Uang Beredar dan Tingkat Inflasi di Indonesia Periode 1984-2014. Jurnal Ekonomi Pembangunan Universitas Udayana. Hal. 533 - 563. 2017.

[5] Afrizal. Analisis Kausalitas Inflasi dan Jumlah Uang Beredar di Indonesia Periode Tahun 2000.1- 2014.4. Jurnal Ekonomi Bisnis dan Kewirausahaan. Hal. 236-250. 2017.

[6] Eubank, R. Spline Smoothing and Nonparametric Regression. Marcel Dekker. New York. 1998.

[7] Rosenblatt, M. Remarks on Some Nonparametric Estimates of a Density Function. The Annals of Mathematical Statistics. 27 (3): 832-837. 1956.

[8] Parzen, E. On Estimation of a Probability Density Function and Mode. The Annals of Mathematical Statistics. 33 (3): 1065-1076. 1962. 
[9] Nadaraya, E. A. On Estimating Regression. Theory of Probability an Its Applications. 9(1): 141-142. 1964.

[10] Watson, G. S. Smooth Regression Analysis. Sankhya: The Indian Journal of Statistics, Series A. 26 (4): 359-372. 1964.

[11] Green, P. J. and Silverman, B. Nonparametrik Regression and Generalized Linear Models (a Roughness Penalty Approach). Chapman and Hall. New York. 1994.

[12] Wand, M. and Jones, M. Kernel Smoothing. Chapman and Hall. London. 1995. 